\title{
Biofilm Ecology of Wooden Shelves Used in Ripening the French Raw Milk Smear Cheese Reblochon de Savoie
}

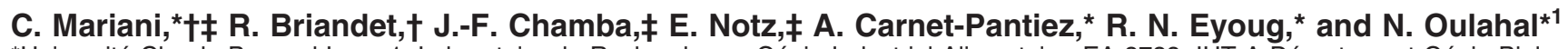 \\ *Université Claude Bernard Lyon 1, Laboratoire de Recherche en Génie Industriel Alimentaire, EA 3733, IUT A Département Génie Biologique, \\ Bourg en Bresse, F-01060 France \\ †Unité Mixte de Recherche 763-UBHM, Institut National de la Recherche Agronomique et Ecole Nationale Supérieure des Industries Agricoles \\ et Alimentaires, Massy, F-91744 France \\ łlnstitut Technique Français des Fromages, La Roche sur Foron, F-74801 France
}

\begin{abstract}
Little work has been carried out on the microbiology of wooden shelves supporting cheese during ripening, and the safety of their use during cheese ripening has frequently been asked. Microbial characterization (enumerations on specific growth media) and description of their physicochemical conditions $(\mathrm{pH}$, water activity, and salt concentration) were determined on 50 wooden shelves of 3 different ages at the end of the cheeseripening process, using cheeses from 8 farm producers. The experiments were performed during 2 different seasons (summer and autumn). Micrococci-corynebacteria and yeasts and molds were found to be the dominant microflora on the shelves. Leuconostocs, facultative heterofermentative lactobacilli, enterococci, staphylococci, and pseudomonads were also found but at lower levels. There was no statistical difference in the major microflora between shelves of different ages. Moreover, the total counts and the predominant microflora showed a surprising homogeneity between origins of cheeses. For most of the microflora enumerated, no seasonal variation was observed. Regardless of the age of the shelves, the wood had high water activity values ( 0.94 to 0.97 ), neutral $\mathrm{pH}$ values (7.1 to 8.3), and low salt contents $\left(0.11\right.$ to $0.17 \mathrm{mg} / \mathrm{cm}^{2}$ ). The origins of the cheese had a statistically significant impact on water activity, $\mathrm{pH}$, and salt concentration, whereas the age of the shelves did not influence these parameters. This study demonstrated the stability of the technological biofilm present on wooden shelves and will serve to enlarge the debate on the use of wood in cheese ripening.

Key words: wooden shelf, biofilm, ecology, ripening
\end{abstract}

\section{INTRODUCTION}

Wood has a long tradition as a natural material used in food production. Today, some traditional foods; for

Received March 31, 2006.

Accepted November 24, 2006.

${ }^{1}$ Corresponding author: oulahal@iutbourg.univ-lyon1.fr example, cheeses and alcoholic beverages, are still produced in contact with this natural material (for maturation or packaging purposes). The amount of cheese ripened on wood is estimated to be greater than 350,000 tonnes per year in France, especially in Registered Designation of Origin productions. Most cheese manufacturers believe that wooden shelves favor cheese rind development and improve the organoleptic qualities and typicality of cheeses. Moreover, such shelves offer excellent mechanical resistance. However, the presence of water and nutrients as well as the porosity of this material may favor microbial development and limit the efficiency of the cleaning procedure. As far as regulations are concerned, wood can be used in the ripening of traditional cheeses under a European derogation law (decision 96/536/CE of July 29, 1996). Very few studies have focused on the interactions between wood and microorganisms and on the hygienic status of wood in food plants. In addition, the few existing reports are contradictory as synthesized by Carpentier (1997). Gehrig et al. (2000) indicated that in dry environments wooden surfaces were not less hygienic than polyethylene surfaces. Moreover, no growth of bacteria was observed $24 \mathrm{~h}$ after depositing $2.4 \times 10^{2}$ cells of Escherichia coli on a dry, poplar wooden crate, whereas bacterial development occurred on a glass surface under the same conditions (Revol-Junelles et al., 2005). Some recommendations for safe use of wood in food processing have been suggested by several authors: dry storage, careful handling, selection of wood species (pine, oak; Prechter et al., 2002; Schönwälder et al., 2002; Milling et al., 2005). Other studies have reported that inert polymers were consistently more hygienic than wooden surfaces that allowed bacterial retention after food service washing (Welker et al., 1997). The potential for cross-contamination has also been demonstrated for wooden and polymeric chopping boards with significant increased persistence of bacteria on wood (Gough and Dodd, 1998). The microbial characterization of a biofilm present on wood was first described in the study of 
Swaffield et al. (1997), where bacteria (lactic and acetic acid bacteria) and yeasts were isolated from cider fermentation vats. Within $2 \mathrm{wk}$, microorganisms penetrated into the porous material to a depth of $1.2 \mathrm{~cm}$. The influence of these stable biofilms on the organoleptic profiles of ciders has also been demonstrated. In cheese technology, the microbial ecosystems have classically been analyzed by enumeration on selective media and more recently by biomolecular techniques (Duthoit et al., 2003; Ogier et al., 2004) or Fourier-transform infrared microspectroscopy (Wenning et al., 2006). Influence of the milk origin (cow or goat; Bockelmann and HoppeSeyler, 2001), production under farmhouse or industrial cheese (Feurer et al., 2004), and the anti-Listeria potential (Maoz et al., 2003) of cheese surface ecosystem have been compared. To our knowledge, there has been no publication on the microbial profile of the wooden shelves used in cheese ripening. One publication has described microbial development on wood by direct observation after $1 \mathrm{wk}$ of daily contact with whey and 3 $\mathrm{d}$ of cheese production (Richard, 1997). Therefore, there is a clear need for systematic investigation of the microbiological ecosystems on wooden shelves during ripening and to assess the hygienic status of this traditional material. The aim of the present study was to describe the natural biofilms on wooden shelves used for the ripening of Registered Designation of Origin Reblochon de Savoie. The enumeration of the main bacteria and yeasts was determined on wooden shelves used in ripening cheese of different origins on selective agar. The physicochemical properties $\left[\mathrm{pH}\right.$, water activity $\left(\mathbf{a}_{\mathbf{w}}\right)$, and salt concentration] of the wood were also determined. These data will serve to help in the debate of the use of wood in cheese ripening.

\section{MATERIALS AND METHODS}

\section{Cheesemaking and Ripening Process}

Reblochon de Savoie is a raw milk smear cheese produced in the French Alps. The first step of cheesemaking consists of an inoculation of the milk with Streptococcus thermophilus and Lactobacillus bulgaricus. Occasionally, Lactococcus lactis and Geotrichum candidum (rarely) will be used. Then, 30 min after calf rennet addition, the curd is cut and gently stirred to eliminate whey. The curd is molded and gently pressed for few hours, then salted in brine for $2 \mathrm{~h}$. The first part of the ripening takes place on the producer's farm at $17^{\circ} \mathrm{C}$ with $95 \%$ relative humidity before the cheeses are bought by a traditional ripener who finishes the ripening on wooden shelves for $2 \mathrm{wk}$. Cheeses are usually smeared (washed with a salted solution) twice: by the cheesemaker and by the ripener.
The traditional ripener in the present study bought cheeses from 20 different farms, $7 \mathrm{~d}$ after their manufacture. Cheeses were laid on wooden shelves, chosen at random after a brush with cold water and an air-dry, during a 2-stage ripening, occurring in 2 ripening rooms. In the first one $\left(13^{\circ} \mathrm{C}\right.$ and $95 \%$ relative humidity), cheeses were smeared once, and the shelves holding the cheeses were changed daily. In the second ripening room $\left(14^{\circ} \mathrm{C}\right.$ and $95 \%$ relative humidity), the shelves were not changed daily and were in contact with the same cheeses for 5 to $9 \mathrm{~d}$, without smearing. The shelves were cut lengthwise from spruce wood (Picea abies) and had been used in cheese ripening from 6 mo to $14 \mathrm{yr}$. Their visual aspects differed according to their age, becoming darker and smoother through use. Each shelf had 14 marks on each side corresponding to the contact zones of the cheeses and were more visible on the older shelves. These points led us to choose the end of the ripening time in the second ripening room to describe the biofilm ecology because at this stage the biofilm was most representative on shelves.

For transport to the laboratory for experiments (2 h), the shelves analyzed in the autumn were wrapped in 2 layers of clingfilm, and placed between 2 shelves with the same humidity rate in a thermal insulated box. During the summer study, the shelves could not be transported, and the original biofilm removal was achieved in the ripening rooms.

\section{Factors Studied}

The ripening process described above led to testing 2 variables: the age of shelves (time between first use and the experiment) and the origin of cheeses put on the shelves (the farmhouses on which the cheeses were made). A total of 50 shelves were analyzed, 10 during the summer and 40 in the autumn. Three ages of shelves were tested for shelves: less than $4 \mathrm{yr}$ old (young), from 5 to $8 \mathrm{yr}$ old (medium), and more than 8 yr old (old) for the autumn study, but only young and old shelves were analyzed in the summer. Cheeses from 8 farmhouses origins were tested, each of which resulted usually in cheeses with different organoleptic features (farmhouses A to $\mathrm{H}$ ) for the autumn experiments and 5 farmhouse origins (A to E) for the summer ones. To assess the interaction between these factors, in autumn, 40 shelves were analyzed [8 origins $\times 5$ shelves ( 2 young, 1 medium, 2 old)].

To analyze the influence of the season, only cheeses from farmhouses $\mathrm{A}$ to $\mathrm{E}$ and the youngest and oldest shelves were compared. This comparison was based on 35 shelves: 10 shelves for the summer study [5 origins $\times 2$ shelves (1 young, 1 old)] and 25 shelves for the 
main autumnal study [ 5 origins $\times 5$ shelves $(2$ young, 1 medium, 2 old)].

\section{Physicochemical Characterization of Wooden Shelves}

For each shelf, $\mathrm{pH}$, water activity $\left(\mathbf{a}_{\mathbf{w}}\right)$, and salt concentration were analyzed on 3 separate marks (40 results obtained on 40 shelves). To analyze $\mathrm{pH}$, one drop of distilled water was placed on the mark. After $10 \mathrm{~min}$ at $20^{\circ} \mathrm{C}$, a color-coded strip (Neutralit pH5-10, Merck, Darmstadt, Germany) was placed in the water on the shelf, and the $\mathrm{pH}$ was recorded. Preliminary experiments on wooden shelves showed good agreements between $\mathrm{pH}$ values determined by this strip technique and direct measurement of $\mathrm{pH}$ with a surface electrode. For $\mathrm{a}_{\mathrm{w}}$ determination, each value was a mean of 3 measurements performed with a dew point instrument (FAst/1, GBX Scientific Instruments, Romans sur Isere, France). The salt concentration was determined on sawdust obtained by sandpapering a cheese mark to a depth of $1 \mathrm{~mm}$. The sawdust $(1 \mathrm{~g})$ was mixed with $50 \mathrm{~mL}$ of distilled water and decanted for $1 \mathrm{~h}$ at room temperature, after which chloride ions in the liquid were analyzed with a chloride-meter (No. 926, Corning International, New York, NY).

\section{Removal of Biofilm by Ultrasound}

In the autumn study, biofilms were removed from 2 cheese contact points on each shelf ( 80 results) in the laboratory, whereas removal was made on one mark (10 results) in the ripening rooms for the summer study. A portable sonicator (Branson Ultrasonics, Annemasse, France) with a fundamental resonant frequency of $\sim 40$ $\mathrm{kHz}$ was used as described previously (Oulahal-Lagsir et al., 2003). Briefly, ultrasound waves were applied for $10 \mathrm{~s}$ in an active chamber filled with $15 \mathrm{~mL}$ of sterile one-quarter strength Ringer's solution (Biokar, Beauvais, France) directly on $10 \mathrm{~cm}^{2}$ of wood biofilm. The solution was then homogenized and put in a sterile flask. After a storage at $4^{\circ} \mathrm{C}$ for $24 \mathrm{~h}$ for the summer study and immediately after the removal for the autumn study, the microbial suspension obtained was mixed (vol/vol) with a sterile milk solution $(110 \mathrm{~g} / \mathrm{L}$, Prolait, Eurial Poitouraine, Jaunay Clan, France) supplemented with $10 \%$ (wt/vol) glycerol (Sigma, St. Louis, MO) before freezing at $-80^{\circ} \mathrm{C}$ (Chamba et al., 2005).

\section{Microbial Enumerations of Suspended Biofilms}

The frozen samples of suspended biofilms were thawed at $20^{\circ} \mathrm{C}$ for $20 \mathrm{~min}$, after a maximum $6 \mathrm{mo}$ frozen storage at $-80^{\circ} \mathrm{C}$ and were directly plated in duplicate on the surface of different media using a spiral plater (Interscience, Saint Nom La Breteche, France) directly from the cryoconserved suspension or after 10fold dilutions in one-quarter strength Ringer's solution. All media were purchased from Biokar, except Pseudomonas aeromonas selective agar, which was purchased from Merck. All the antibiotics were purchased from Sigma, except amphotericin B and penicillin G, which were from Calbiochem (Fontenay-sous-Bois, France).

The total microbial population was enumerated on plate count agar after $7 \mathrm{~d}$ at $20^{\circ} \mathrm{C}$.

Enumeration of micrococci and corynebacteria was performed on micrococci-corynebacteria medium (inhouse formulation, ITFF-Aérial), which contained in 1 L: $15 \mathrm{~g}$ of tryptone (Difco, Le Pont-De-Claix, France), $5 \mathrm{~g}$ of soy peptone (Difco), $6 \mathrm{~g}$ of yeast extract (Difco), $20 \mathrm{~mL}$ of sodium lactate (60\% solution wt/wt; Merck), $2.5 \mathrm{~g}$ of dipotassium phosphate (Merck), $40 \mathrm{~g}$ of sodium chloride (Merck), $15 \mathrm{~g}$ of bacteriological agar (Biokar). After sterilization and cooling to $45^{\circ} \mathrm{C}$, furazolidone (10 $\mathrm{mg} / \mathrm{L})$, nalidixic acid ( $40 \mathrm{mg} / \mathrm{L})$, and amphotericin B (80 $\mathrm{mg} / \mathrm{L}$ ) were added. Agar plates were incubated for $5 \mathrm{~d}$ at $20^{\circ} \mathrm{C}$.

Yeasts and molds were enumerated using chloramphenicol glucose agar after $5 \mathrm{~d}$ at $20^{\circ} \mathrm{C}$.

To enumerate presumptive staphylococci, cheese ripening bacteria medium (Denis et al., 2001) was used supplemented with bacitracin (30 $\mathrm{mg} / \mathrm{L})$, nalidixic acid $(40 \mathrm{mg} / \mathrm{L})$, and amphotericin B $(80 \mathrm{mg} / \mathrm{L})$. Agar plates were incubated for $5 \mathrm{~d}$ at $20^{\circ} \mathrm{C}$ in an anaerobic atmosphere, without an enrichment in $\mathrm{CO}_{2}$. The coagulase test was not performed.

Pseudomonads were enumerated on Pseudomonas aeromonas selective agar to which penicillin $\mathrm{G}$ (57.8 $\mathrm{mg} / \mathrm{L})$ and amphotericin B ( $80 \mathrm{mg} / \mathrm{L})$ were added after incubation for $3 \mathrm{~d}$ at $20^{\circ} \mathrm{C}$.

Enterococci were enumerated on bile esculin azide agar after $2 \mathrm{~d}$ incubation at $37^{\circ} \mathrm{C}$.

To assess leuconostocs, the Nickels and Leesment medium (Nickels and Leesment, 1964) was used with the addition of vancomycin $(170 \mathrm{mg} / \mathrm{L})$ and amphotericin $B(80 \mathrm{mg} / \mathrm{L})$. Agar plates were incubated for $5 \mathrm{~d}$ at $20^{\circ} \mathrm{C}$.

For the facultatively heterofermentative lactobacilli population, the facultatively heterofermentative medium of Isolini et al. (1990) was used with incubation for $3 \mathrm{~d}$ at $37^{\circ} \mathrm{C}$ in an anaerobic atmosphere, without an enrichment in $\mathrm{CO}_{2}$.

Coliforms were enumerated on violet red bile lactose after $24 \mathrm{~h}$ at $30^{\circ} \mathrm{C}$.

\section{Scanning Electron Microscopy of Wooden Shelves}

Wooden samples were fixed for $1 \mathrm{~h}$ in a glutaraldehyde solution ( $3 \% \mathrm{vol} / \mathrm{vol})$, rinsed 3 times for $10 \mathrm{~min}$ in 


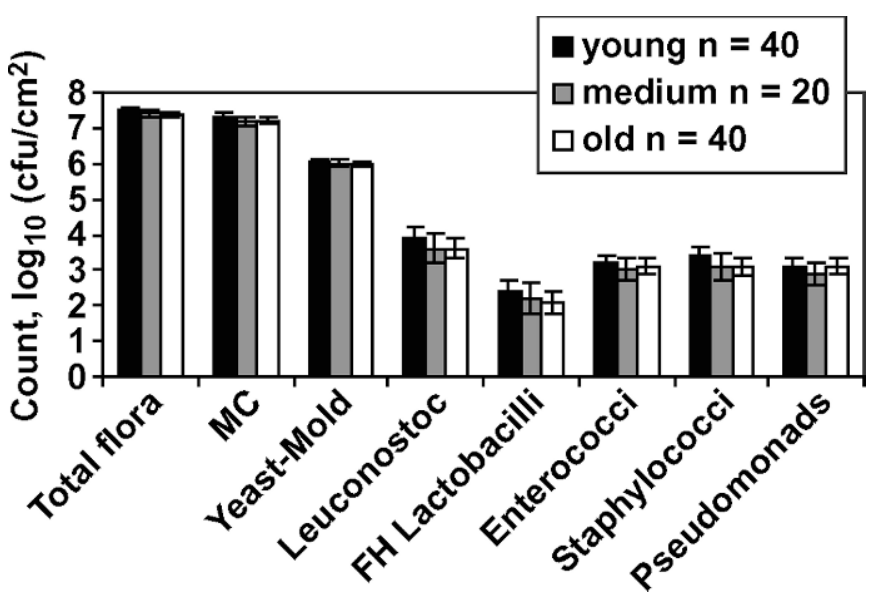

Figure 1. Effect of age of wooden shelf on the means of the counts of different groups of microorganisms on wooden shelves $\left(\log _{10}(\mathrm{cfu} /\right.$ $\left.\mathrm{cm}^{2}\right)$. Error bars indicate confidence interval $(P<0.05)$. Young $=$ less than $4 \mathrm{yr}$ old; medium $=$ from 5 to $8 \mathrm{yr}$ old; old $=$ more than $8 \mathrm{yr}$ old . $\mathrm{MC}=$ micrococci-corynebacteria; $\mathrm{FH}=$ facultatively heterofermentative.

a sodium cacodylate solution $(0.2 \mathrm{M}, \mathrm{pH}=7.4)$, dehydrated in a succession of 12 alcohol baths of increasing alcohol concentrations (increase of $3 \%$ between each bath, from 70 to $100 \% \mathrm{vol} / \mathrm{vol}$ ), and coated with gold in a cathode vacuum evaporator (Jeol JFC 1102, Tokyo, Japan). Observations of samples were made using a Hitachi S-4500 scanning electron microscope (Ibaraki, Japan), at an accelerating voltage of $10 \mathrm{kV}$.

\section{Statistical Analysis}

All counts were expressed as $\log _{10}\left(\mathrm{cfu} / \mathrm{cm}^{2}\right)$. To evaluate the influence of time, origin of cheese, and age of shelves on the microbial levels, and physicochemical values, an ANOVA was performed with Splus 2000 (Mathsoft, Seattle, WA). The principal effects and inter- actions were estimated using ANOVA variance analysis (type III sum of squares for unbalanced groups) and mean comparison (Bonferroni test, with a significant level of $P<0.05$ ).

\section{RESULTS}

\section{Influence of Age of Shelf, Origin of Cheese, and Season on Microbial Flora of Wood Biofilms}

In the main statistical analysis of the 40 shelves, standard errors were based on 95 degrees of freedom, and there was no interaction between age and origin for microbial numbers or physicochemical values. Figure 1 summarizes the microbial counts of the spoiling flora (at the origin of deterioration of cheese), the lactic acid flora and the micrococci-corynebacteria, and yeasts and molds, both of which compose the major surface flora of technological interest (at the origin of the typicality of rinds; $\log _{10} \mathrm{cfu} / \mathrm{cm}^{2}$ ) according to the age of the wooden shelves. Micrococci-corynebacteria [7.2 to $7.3 \log _{10}(\mathrm{cfu} /$ $\left.\left.\mathrm{cm}^{2}\right)\right]$, and yeasts and molds [6.0 to $\left.6.1 \log _{10}\left(\mathrm{cfu} / \mathrm{cm}^{2}\right)\right]$ were found to be the dominant microflora on the shelves. Among the yeasts and molds, Geotrichum candidum was the most common species. Leuconostocs [3.7 $\left.\log _{10}\left(\mathrm{cfu} / \mathrm{cm}^{2}\right)\right]$, facultative heterofermentative lactobacilli $\left[2.2 \log _{10}\left(\mathrm{cfu} / \mathrm{cm}^{2}\right)\right]$, and enterococci [3.1 $\log _{10}(\mathrm{cfu} /$ $\left.\mathrm{cm}^{2}\right)$ ], to some extent, were found at much lower levels on the wooden shelves. Staphylococci [3.2 $\log _{10}(\mathrm{cfu} /$ $\left.\left.\mathrm{cm}^{2}\right)\right]$ and pseudomonads $\left[3.0 \log _{10}\left(\mathrm{cfu} / \mathrm{cm}^{2}\right)\right]$ were enumerated on 80 samples. There was no statistical difference in any microflora between shelves of different ages $(P<0.05)$.

Table 1 and Figure 2 show the levels of the different groups of microorganisms on wooden shelves according to origins of cheese (A to $\mathrm{H}$ ). The total count and the predominant microflora (micrococci-corynebacteria and yeast-molds) showed a surprising homogeneity between

Table 1. Comparison of the total counts and the counts of different groups of microorganisms on wooden shelves $\left(\log _{10}\left(\mathrm{cfu} / \mathrm{cm}^{2}\right)\right.$ according to the farmhouse origin where cheeses were ripened (mean $\pm \mathrm{SEM} ; \mathrm{n}=$ 80)

\begin{tabular}{|c|c|c|c|c|c|}
\hline & Leuconostoc & $\begin{array}{c}\text { Facultatively } \\
\text { heterofermentative } \\
\text { lactobacilli }\end{array}$ & Enterococci & Staphylococci & Pseudomonads \\
\hline Farm origin & $* * *$ & $* * *$ & $* * *$ & $* * *$ & $* * *$ \\
\hline $\mathrm{A}(\mathrm{n}=10)$ & $4.3 \pm 0.27^{\mathrm{a}}$ & $2.4 \pm 0.29^{\mathrm{ab}}$ & $3.2 \pm 0.21^{\mathrm{b}}$ & $2.9 \pm 0.25^{\mathrm{b}}$ & $0.9 \pm 0.20^{\mathrm{d}}$ \\
\hline $\mathrm{B}(\mathrm{n}=10)$ & $4.5 \pm 0.27^{\mathrm{a}}$ & $1.4 \pm 0.29^{b}$ & $4.0 \pm 0.21^{\mathrm{ab}}$ & $4.8 \pm 0.25^{\mathrm{a}}$ & $4.8 \pm 0.20^{\mathrm{a}}$ \\
\hline$C(\mathrm{n}=10)$ & $2.8 \pm 0.27^{\mathrm{b}}$ & $1.4 \pm 0.29^{\mathrm{b}}$ & $2.2 \pm 0.21^{\mathrm{c}}$ & $2.1 \pm 0.25^{\mathrm{b}}$ & $2.5 \pm 0.20^{\mathrm{c}}$ \\
\hline $\mathrm{D}(\mathrm{n}=10)$ & $3.2 \pm 0.27^{b}$ & $2.1 \pm 0.29^{b}$ & $3.3 \pm 0.21^{\mathrm{b}}$ & $3.1 \pm 0.25^{b}$ & $3.6 \pm 0.20^{\mathrm{b}}$ \\
\hline$E(n=10)$ & $3.6 \pm 0.27^{\mathrm{ab}}$ & $2.0 \pm 0.29^{b}$ & $2.6 \pm 0.21^{\mathrm{c}}$ & $3.0 \pm 0.25^{\mathrm{b}}$ & $3.5 \pm 0.20^{\mathrm{b}}$ \\
\hline $\mathrm{F}(\mathrm{n}=10)$ & $4.6 \pm 0.27^{\mathrm{a}}$ & $3.8 \pm 0.29^{\mathrm{a}}$ & $4.3 \pm 0.21^{\mathrm{a}}$ & $3.9 \pm 0.25^{\mathrm{a}}$ & $4.4 \pm 0.20^{\mathrm{a}}$ \\
\hline $\mathrm{G}(\mathrm{n}=10)$ & $3.2 \pm 0.27^{\mathrm{b}}$ & $2.0 \pm 0.29^{\mathrm{b}}$ & $2.2 \pm 0.21^{\mathrm{c}}$ & $2.8 \pm 0.25^{\mathrm{b}}$ & $2.5 \pm 0.20^{\mathrm{c}}$ \\
\hline $\mathrm{H}(\mathrm{n}=10)$ & $3.4 \pm 0.27^{\mathrm{b}}$ & $2.8 \pm 0.29^{\mathrm{ab}}$ & $3.1 \pm 0.21^{\mathrm{bc}}$ & $3.0 \pm 0.25^{\mathrm{b}}$ & $1.5 \pm 0.20^{\mathrm{d}}$ \\
\hline
\end{tabular}

${ }^{\mathrm{a}-\mathrm{d}}$ Means within a row with different superscripts differ.

$* * * P<0.001$. 


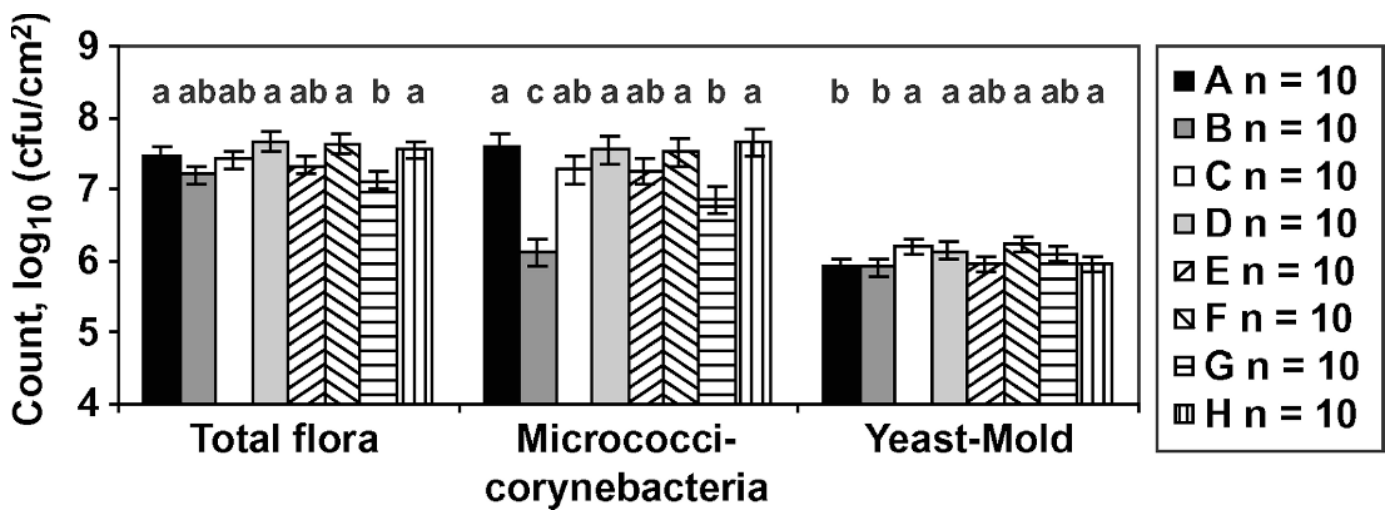

Figure 2. Effect of the cheese producing farmhouses (A to $\mathrm{H}$ ) on the means of the total bacterial counts, the micrococci-corynebacteria, and the yeast-mould on wooden shelves $\left(\log _{10}\left(\mathrm{cfu}_{\mathrm{c}} / \mathrm{cm}^{2}\right)\right.$. Error bars indicate confidence interval $(P<0.05)$. ${ }^{\mathrm{a}-\mathrm{C}}$ Letters correspond to statistically different groups.

these 8 origins of cheeses. The greatest differences for the total count, the micrococci and corynebacteria (excluding cheese $\mathrm{B}$ ), and the yeasts and molds were 0.56 , 0.81 , and $0.33 \log _{10}\left(\mathrm{cfu} / \mathrm{cm}^{2}\right)$, respectively. The B origin of cheese had a count of micrococci and corynebacteria $\sim 1$ to $1.5 \log _{10}\left(\mathrm{cfu} / \mathrm{cm}^{2}\right)$ lower compared with the other cheeses.

To assess the seasonal influence and stability of the shelf microbiological profiles, the autumn and summer results were compared (Figure 3). For most of the microbial groups enumerated, no seasonal variability was observed $(P<0.05)$, but statistical differences were found for staphylococcal and pseudomonads populations. For these 2 groups, levels increased by $1.0 \log _{10}(-$ $\left.\mathrm{cfu} / \mathrm{cm}^{2}\right)$ for the staphylococci and $1.4 \log _{10}\left(\mathrm{cfu} / \mathrm{cm}^{2}\right)$ for

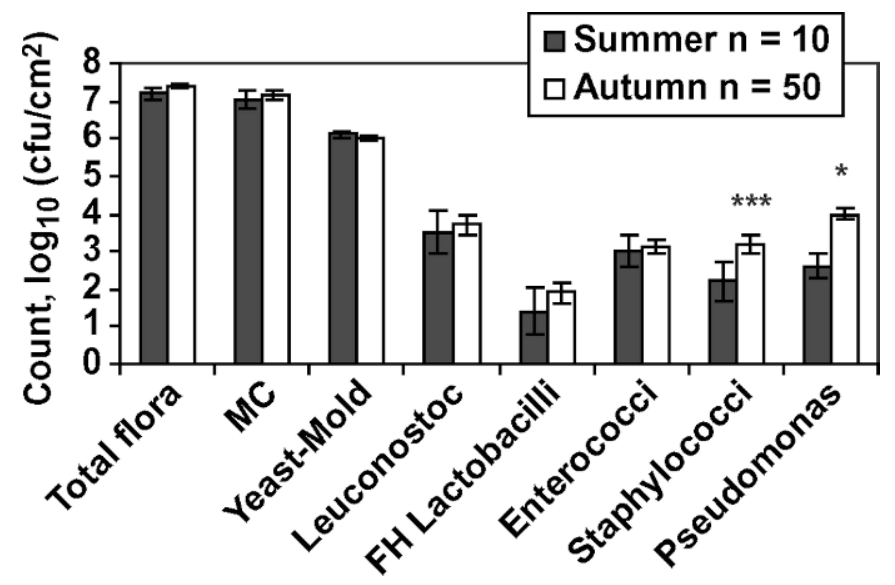

Figure 3. Effect of season on the means of the total bacterial counts and the 7 different groups of microorganisms on wooden shelves $\left(\log _{10}\left(\mathrm{cfu} / \mathrm{cm}^{2}\right)\right.$. Error bars indicate confidence interval $(P<0.05)$. Summer: samples collected from June to July. Autumn: samples collected from October to November. $\mathrm{MC}=$ micrococci-corynebacteria; $\mathrm{FH}=$ facultatively heterofermentative. ${ }^{* * *} P<0.001 ;{ }^{*} P<0.05$. the pseudomonads from summer to autumn (respectively $P<0.001$ and $P=0.029$, standard errors based on 50 degrees of freedom). Some differences were observed among cheeses of different origins: shelves in contact with $\mathrm{B}$ cheese origin showed a significant decrease in total microflora $\left[0.72 \log _{10}\left(\mathrm{cfu} / \mathrm{cm}^{2}\right) ; P<0.001\right]$, in micrococci and corynebacteria levels $\left[1.23 \log _{10}\left(\mathrm{cfu} / \mathrm{cm}^{2}\right) ; P<\right.$ 0.001; data not shown). Shelves in contact with cheese A exhibited a significant decrease $(P=0.005)$ of the pseudomonad level [1.0 $\log _{10}\left(\mathrm{cfu} / \mathrm{cm}^{2}\right)$; data not shown]. Figure 3 also clearly shows that confidence intervals were smaller for the total and main microflora than for the others. In addition, coliforms were also enumerated in the summer, and all enumerations were below 2.2 $\log _{10}\left(\mathrm{cfu} / \mathrm{cm}^{2}\right)$ and most under $0.3 \log _{10}\left(\mathrm{cfu} / \mathrm{cm}^{2}\right)$.

\section{Scanning Electron Microscopy Observations of Shelf Biofilms}

Figure 4 presents the scanning electron microscopy of the shelf biofilms at the end of the ripening ( $\mathrm{C}$ origin, medium aged shelf). From these micrographs, it is obvious that the nutrients in the wooden ripening shelves promote microbiological growth because bacteria ( 1 to $2 \mu \mathrm{m}$ cells) and yeasts $(>5 \mu \mathrm{m})$ were visible on wood fibers at high levels, mostly in cracks, apertures, and pores of wood. The smaller the cells were (bacteria), the more they colonized the cracks and small cavities of wood. Identifiable morphology of vegetative Geotrichum candidum cells (cylinders of around $10 \mu \mathrm{m}$ ) could be seen throughout the sample. Filamentous structures of those technologically important cells could be seen along the wood fibers, indicating a constricted yeast multiplication in that environment. However, the microbial biofilm did not cover all the surface of the shelf. 

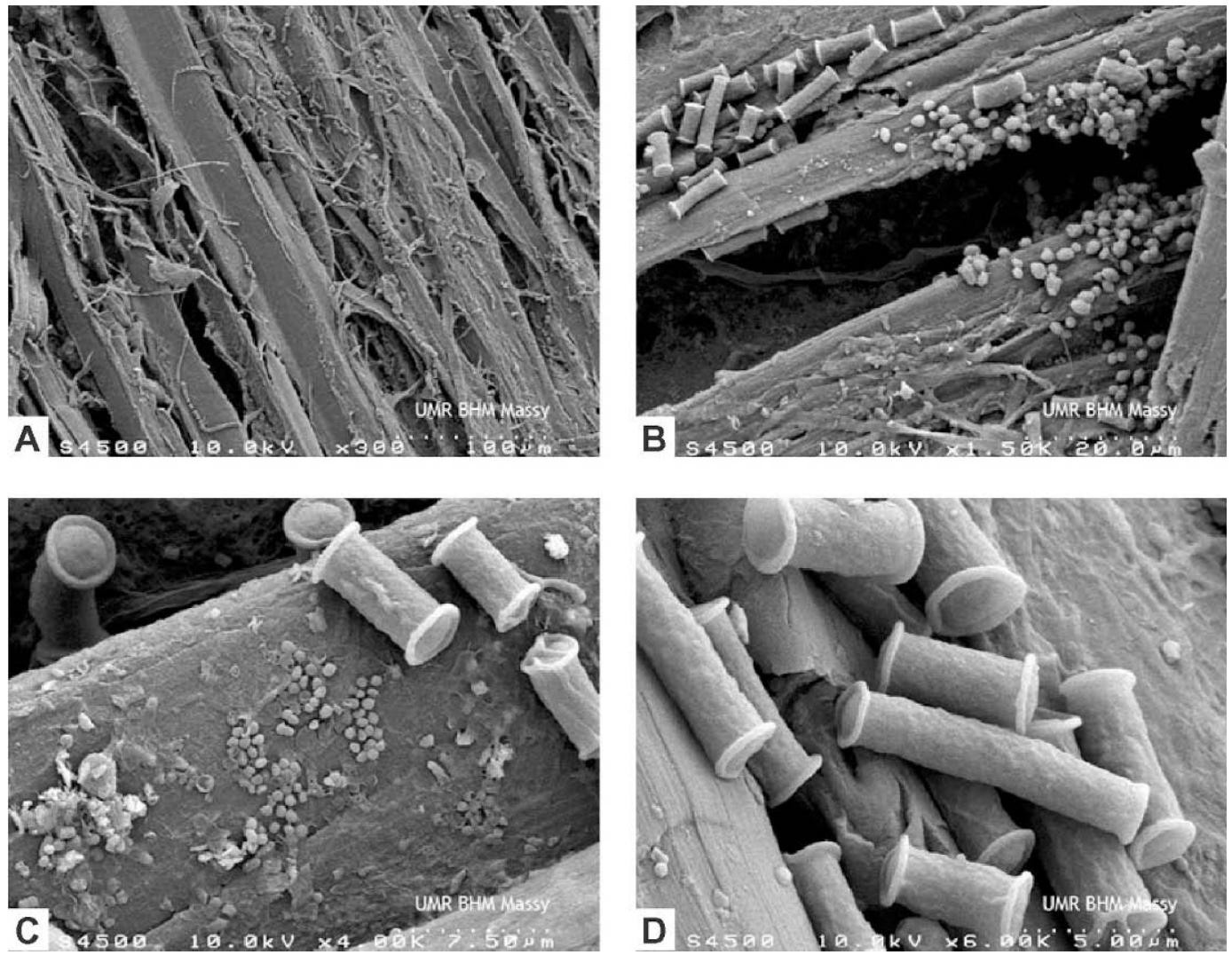

Figure 4. Scanning electron microscopy of the surface of a ripening shelf. A $(\times 300)$, ripening biofilm does not cover all the surface of the shelf. $\mathrm{B}(\times 1,500)$, bacteria are located in the cracks. $\mathrm{C}(\times 4,000)$ and $\mathrm{D}(\times 6,000)$, details of Geotrichum candidum (cylinders) and bacteria.

\section{$p H, a_{w}$, and Salt Concentration of the Shelves}

Table 2 summarizes the physicochemical characteristics of the shelves of different ages (young, medium, old) and cheese origins (A to $\mathrm{H}$ ). Regardless of the shelves, the wood had high $\mathrm{a}_{\mathrm{w}}$ values (in the range 0.942 to 0.971 ), neutral $\mathrm{pH}$ values (7.1 to 8.3 ), and low salt contents $\left(0.11\right.$ to $\left.0.17 \mathrm{mg} / \mathrm{cm}^{2}\right)$. The cheese origin had

Table 2. Comparison of physicochemical values of wooden shelves according to the age of shelves (young, medium, and old) and the farmhouse origin where cheeses were ripened (A to H)

\begin{tabular}{|c|c|c|c|}
\hline Factors $(\mathrm{n}=40)$ & Water activity & $\mathrm{pH}$ & $\begin{array}{c}\text { Salt } \\
\text { concentration } \\
\mathrm{mg} / \mathrm{cm}^{2}\end{array}$ \\
\hline Mean $\pm \mathrm{SE}$ & $0.960 \pm 0.0004$ & $7.6 \pm 0.06$ & $0.14 \pm 0.003$ \\
\hline Farm origin & *** & $* *$ & * \\
\hline$A(n=5)$ & $0.946 \pm 0.0012^{\mathrm{d}}$ & $8.0 \pm 0.17^{\mathrm{a}}$ & $0.15 \pm 0.010^{\mathrm{ab}}$ \\
\hline $\mathrm{B}(\mathrm{n}=5)$ & $0.971 \pm 0.0012^{\mathrm{a}}$ & $7.6 \pm 0.17^{\mathrm{ab}}$ & $0.11 \pm 0.010^{\mathrm{b}}$ \\
\hline $\mathrm{C}(\mathrm{n}=5)$ & $0.957 \pm 0.0012^{\mathrm{c}}$ & $7.6 \pm 0.17^{\mathrm{ab}}$ & $0.16 \pm 0.010^{\mathrm{ab}}$ \\
\hline $\mathrm{D}(\mathrm{n}=5)$ & $0.965 \pm 0.0012^{\mathrm{b}}$ & $7.1 \pm 0.17^{\mathrm{b}}$ & $0.13 \pm 0.010^{\mathrm{ab}}$ \\
\hline $\mathrm{E}(\mathrm{n}=5)$ & $0.969 \pm 0.0012^{\mathrm{b}}$ & $7.5 \pm 0.17^{\mathrm{ab}}$ & $0.15 \pm 0.010^{\mathrm{ab}}$ \\
\hline $\mathrm{F}(\mathrm{n}=5)$ & $0.969 \pm 0.0012^{\mathrm{b}}$ & $7.7 \pm 0.17^{\mathrm{ab}}$ & $0.17 \pm 0.010^{\mathrm{a}}$ \\
\hline $\mathrm{G}(\mathrm{n}=5)$ & $0.957 \pm 0.0012^{\mathrm{c}}$ & $7.2 \pm 0.17^{\mathrm{b}}$ & $0.14 \pm 0.010^{\mathrm{ab}}$ \\
\hline $\mathrm{H}(\mathrm{n}=5)$ & $0.942 \pm 0.0012^{\mathrm{d}}$ & $8.3 \pm 0.17^{\mathrm{a}}$ & $0.16 \pm 0.010^{\mathrm{ab}}$ \\
\hline Age & NS & NS & $* * *$ \\
\hline Young $(\mathrm{n}=16)$ & $0.959 \pm 0.0007$ & $7.6 \pm 0.09$ & $0.15 \pm 0.005^{b}$ \\
\hline Medium $(\mathrm{n}=8)$ & $0.959 \pm 0.0009$ & $7.6 \pm 0.12$ & $0.16 \pm 0.008^{\mathrm{a}}$ \\
\hline Old $(\mathrm{n}=16)$ & $0.960 \pm 0.0006$ & $7.6 \pm 0.09$ & $0.13 \pm 0.005^{\mathrm{c}}$ \\
\hline Age $\times$ origin & NS & NS & NS \\
\hline
\end{tabular}

${ }^{\mathrm{a}-\mathrm{d}}$ Means within a row with different superscripts differ.

$* P<0.05 ; * * P<0.01 ; * * * P<0.001$. 
a statistically significant impact on $\mathrm{a}_{\mathrm{w}}, \mathrm{pH}$, and salt concentration $(P<0.05)$, whereas the age of the shelves did not influence $\mathrm{pH}, \mathrm{a}_{\mathrm{w}}$, and salt concentration (the variation of the parameter is below the precision threshold of the technique). Only a slight correlation between $\mathrm{a}_{\mathrm{w}}$ and pseudomonads enumeration on shelves was observed $\left(\mathrm{R}^{2}=0.64, P<0.001\right)$.

\section{DISCUSSION}

In this project, the native ripening biofilms of wooden shelves and possible major variables that might affect them have been studied for the first time. The results showed that microbial groups on wood ripening biofilm is strongly correlated with the microbial groups of cheese rinds. The main microflora on the rind of Reblochon de Savoie are corynebacteria and yeasts, mostly Geotrichum candidum (Bärtschi et al., 1994; A. Thomas, Institut Technique Français des Fromages, La Roche sur Foron, France, personal communication). In the latter 2 studies, the yeast population was found to be quite diversified, whereas, on the shelves, Geotrichum candidum appeared to be the main yeast. The influence of the wood or differences in ripening techniques on the farm of origin may explain these contradictory results. For the other microbial groups, no data are available for comparison. In the core of cheese, facultatively heterofermentative lactobacilli and leuconostocs enumerations were usually in the range 5 to 6 $\log _{10}(\mathrm{cfu} / \mathrm{g})$. On the shelves, facultatively heterofermentative lactobacilli and leuconostocs are not the dominating flora $\left[<4 \log _{10}\left(\mathrm{cfu} / \mathrm{cm}^{2}\right)\right]$, which was not surprising because lactic acid bacteria were not the main surface microorganisms. Although enterococci are known to have technological potential, they are sometimes considered to be undesirable in cheese (Giraffa, 2003). The presence of staphylococci was also ambivalent; some species have technological interest (lypolysis and antimicrobial activities; Chamba and Irlinger, 2004), but others are pathogenic (e.g., Staphylococcus aureus). The lack of identification of the species of enterococci and staphylococci do not allow us to make any conclusion on the risk associated with the presence of these 2 groups of bacteria on the shelves. But the low levels [means of 3.2 and $3.1 \log _{10}\left(\mathrm{cfu} / \mathrm{cm}^{2}\right)$ ] observed on wooden shelves need to be kept in mind. European Union regulations allow $4 \log _{10}(\mathrm{cfu} / \mathrm{g}$ ) coagulase-positive staphylococci in cheese (law 2073/2005 of November 15, 2005) and staphylococcal toxins are found beyond a level of $5 \log _{10}(\mathrm{cfu} / \mathrm{g})$. In cheese ripening, Pseudomonas spp. are considered as a spoilage microflora because some species can induce taste defects or produce fluorescent dyes that lead to visual defects on rinds (Gram et al., 2002). Usually enumerated only in the raw milk used in cheese making, the wood microenvironment did not seem particularly favorable to their multiplication because they were detected only at low levels [3.0 $\log _{10}(\mathrm{cfu} /$ $\left.\mathrm{cm}^{2}\right)$ ]. Coliforms are another spoilage group that were enumerated at very low levels from the shelves analyzed in the summer $\left[<2.2 \log _{10}\left(\mathrm{cfu} / \mathrm{cm}^{2}\right)\right]$.

Surprisingly, in view of the contrast in the visual aspect of the shelves and their role in water exchanges during ripening, the age of the shelves did not appear to influence the ecosystem or the physicochemical parameters of the wood. Indeed, the ripening partner observed that young shelves (less than 4 yr old) dried cheeses more efficiently than the oldest. To explain these differences, one might point out that $a_{w}$ was a surface measurement, when the water regulation of wood was made by fibers in the entire shelf (Carpentier, 1997). The influence of the age of the shelf on wood porosity needs to be explored further to explain the different drying abilities observed by the ripening partner.

The farmhouse origin of cheeses showed a significant influence on minority microbial populations. This result was not surprising because the origins of the cheese were chosen to represent cheeses with different organoleptic features, and it is known that microbial flora, which is influenced by the environments of breeding and milking, influences the organoleptic qualities of cheeses (Michel et al., 2001; Montel et al., 2003). The origin of the cheeses also showed a significant influence on the $\mathrm{pH}$ and $\mathrm{a}_{\mathrm{w}}$ values, which might be explained by different processing techniques during cheese manufacture and initial ripening by cheesemaker. The $\mathrm{pH}$ variations between cheeses of different origins could be explained by microbial diversity because yeasts are responsible for the increase of the $\mathrm{pH}$ during cheese ripening (Chamba and Irlinger, 2004) and because acidifying properties are influenced by microbial population (Michel et al., 2001). The differences in $a_{w}$ could be explained by different contact times between cheeses and the shelves analyzed. This factor could not be overcome because shelves were analyzed at the same stage, the end of the ripening time in the second ripening room, after 5 to $9 \mathrm{~d}$ of contact between cheeses and shelves. This stage was also chosen in order not to disturb the ripening process. It appeared that the 4 origins with smallest cheese-shelf contact times (cheeses A, C, G, and $\mathrm{H}$ ) had the 4 lowest $\mathrm{a}_{\mathrm{w}}$ values (0.942 to 0.957 ), suggesting that contact time played a role in the $a_{w}$ values of the shelves. The low salt concentration measured on the shelves $(0.11$ to $0.17 \mathrm{mg} /$ $\mathrm{cm}^{2}$ ) was not surprising because Reblochon de Savoie is smeared once in the first ripening room, and the shelves analyzed were taken from the second ripening room, where smearing no longer occurred. 
Very poor statistical relations were found between physicochemical values and levels of the different microbial groups. This can be explained by i) the low variation in the microbial groups whatever the age and the origins of the shelves, and ii) the high compatibility of neutral $\mathrm{pH}$, high $\mathrm{a}_{\mathrm{w}}$, and low salt content with microbiological life, except the 2 lowest $\mathrm{a}_{\mathrm{w}}$ values for Pseudomonas spp. (0.942 and 0.947). Indeed, most yeasts can grow at $\mathrm{a}_{\mathrm{w}}$ values of 0.87 to 0.94 , lactic acid bacteria at 0.91 to 0.95 , halophilic bacteria at 0.75 , and Pseudomonas spp. at 0.95 (Banwart, 1989; Guiraud, 2003). Shelf $\mathrm{pH}$ values (7.1 to 8.3) were also in favor of microbial growth. Indeed, the maximum $\mathrm{pH}$ for growth is about 8.0 to 8.5 for most yeasts and 9.0 for most bacteria (Banwart, 1989). Salt concentrations were determined on the first millimeter on the shelf, which corresponded to the main area of bacteria colonization. To interpret these results, the level of salt on the shelves was calculated to be between 3 and $4 \%$ (wt/wt), which is a level with limited microbiological influence [to compare, the salt level in the physiological saline solution is $9 \%$ (wt/wt)].

Nevertheless, it must be kept in mind that shelves were only analyzed at the end of the ripening cycle, after 5 to $9 \mathrm{~d}$ of contact with the cheeses. The physicochemical parameters and the microbial ecosystems probably vary during ripening, and the study of the dynamic must help to answer the question of the transfer of microorganisms between cheeses and shelves. According to the present study, because the minority microbial populations on shelves were influenced by the farmhouse origins of cheeses, the transfer of these microbial populations might have occurred from the cheeses to the shelves. But the dynamic of the physicochemical parameters may also affect the microbial ecosystem, especially the $\mathrm{a}_{\mathrm{w}}$ after the drying stage, which may apply a selection on microflora.

Moreover, it is necessary to stress the fact that the present study was based on microflora enumerations but not on species identification. Because the diversity of species in corynebacteria was found according to the origins of the Reblochon de Savoie rinds (Bärtschi et al., 1994; A. Thomas, Institut Technique Français des Fromages, La Roche sur Foron, France, personal communication), the identification in the present study might show variations on microflora according to the cheese origins.

All these results, the dominance of the technological surface microflora, the homogeneity according to cheese origin, and the low level of undesirable bacteria, must be linked with the ripening techniques used. Indeed, the ripening procedures of the ripening partner were very strict and concerned cheese-shelf relationships, cheese smearing, and shelf cleaning. These led to the predominance over time of the technological microflora and homogeneous levels of the different groups in cheeses of different origins at the end of the ripening on shelves. On the other hand, undesirable microorganisms were maintained at a low level. The technological microbial profile on wooden shelves (majority of technological microflora) had already been found after only 6 mo of use for shelves, and it appeared to be stable from $6 \mathrm{mo}$ to $14 \mathrm{yr}$ of use in ripening.

To conclude, this study clearly demonstrated that the stability of the technological biofilm present on wooden shelves was linked to rigorous ripening techniques.

Further research on microbial ecology is necessary to explore whether this technological microbial profile is also found at other stages of ripening on shelves, especially on shelves after cleaning. Further description and control of the microbial interactions of stable native biofilms with undesirable microorganisms will be a challenge for the cheese ripeners. The original consortium found on wooden shelves could play an active role in determining the safety of wooden shelves in the traditional ripening process.

\section{ACKNOWLEDGMENTS}

This work was financially supported by the French Association de Coordination Technique pour l'Industrie Agro-alimentaire (ACTIA). We are very grateful to the SARL Joseph Paccard for providing shelves. We also thank Florence Dubois-Brissonnet for MEB analyses. We are indebted to professional partners (Syndicat Interprofessionnel de Reblochon, Arilait Recherches, Comité des Appellations d'Origine Laitières, Entremont-Alliance, Aérial) for their financial and intellectual support.

\section{REFERENCES}

Banwart, G. J. 1989. Basic Food Microbiology. 2nd ed. Van Nostrand Reinhold, New York, NY.

Bärtschi, C., J. Berthier, and G. Valla. 1994. Evolution of the surface fungal flora of Reblochon cheese. Lait 74:105-114.

Bockelmann, W., and T. Hoppe-Seyler. 2001. The surface micro-flora of bacterial smear-ripened cheeses from cow's and goat's milk. Int. Dairy J. 11:307-314.

Carpentier, B. 1997. Sanitary quality of meat chopping board surfaces: A bibliographical study. Food Microbiol. 14:31-37.

Chamba, J. F., C. Beal, C. Delbes, M. C. Montel, J. M. Panoff, B. Thammavongs, and A. Thomas. 2005. Sauvegarde de consortia microbiens fromagers: Mise au point de methodes de conservation ex situ à long terme. Les Actes du Bureau des Ressources Génétiques. 5:393-409.

Chamba, J. F., and F. Irlinger. 2004. Secondary and adjunct cultures. Pages 191-206 in Cheese: Chemistry, Physics and Microbiology. Vol. 1. Elsevier, Amsterdam, the Netherlands.

Denis, C., M. Gueguen, E. Henry, and D. Levert. 2001. New media for the numeration of cheese surface bacteria. Lait 81:365-379.

Duthoit, F., J. J. Godon, and M. C. Montel. 2003. Bacterial community dynamics during production of Registered Designation of Origin 
Salers Cheese as evaluated by $16 \mathrm{~S}$ rRNA gene single-strand conformation polymorphism analysis. Appl. Environ. Microbiol. 69:3840-3848

European Commission. 1996. 96/536/EC: Commission Decision of 29 July 1996 establishing the list of milk-based products in respect of which Member States are authorized to grant individual or general derogations pursuant to Article 8 (2) of Directive 92/46/ EEC and the nature of the derogations applicable to the manufacture of such products. JO L230/12 of the 11 September 1996.

European Commission. 2005. Commission Regulation (EC) No 2073/ 2005 of 15 November 2005 on microbiological criteria for foodstuffs. JO L338/1 of the 22 December 2005.

Feurer, C., F. Irlinger, H. E. Spinnler, P. Glaser, and T. Vallaeys. 2004. Assessment of the rind microbial diversity in a farmhouseproduced vs a pasteurized industrially produced soft red-smear cheese using both cultivation and rDNA-based methods. J. Appl. Microbiol. 97:546-556.

Gehrig, M., G. Schnell, E. Zürcher, and L. J. Kucera. 2000. Hygienic aspects of wood and polyethylen cutting boards regarding food contaminations. A comparison. Holz als Roh- und Werkstoff. 58:265-269.

Giraffa, G. 2003. Functionality of enterococci in dairy products. Int. J. Food Microbiol. 88:215-222.

Gough, N. L., and C. E. R. Dodd. 1998. The survival and disinfection of Salmonella typhimurium on chopping board surfaces of wood and plastic. Food Contr. 9:363-368.

Gram, L., L. Ravn, M. Rasch, J. B. Bruhn, A. B. Christenen, and M. Givskov. 2002. Food spoilage-interactions between food spoilage bacteria. Int. J. Food Microbiol. 78:79-97.

Guiraud, J. P. 2003. Microbiologie alimentaire. Dunod, Paris, France.

Isolini, D., M. Grand, and H. Glättli. 1990. Selecktivmediem zum Nachweis von obligat und fakultativ heterofermentativen Laktobazillen. Schweiz. Milchw. Forschung. 19:57-59.

Maoz, A., R. Mayr, and S. Scherer. 2003. Temporal stability and biodiversity of two complex antilisterial cheese-ripening microbial consortia. Appl. Environ. Microbiol. 69:4012-4018.

Michel, V., A. Hauwuy, and J. F. Chamba. 2001. Raw cow milk microflora: Diversity and influence of conditions of production. Lait 81:575-592.
Milling, A., R. Kehr, A. Wulf, and K. Smalla. 2005. Survival of bacteria on wood and plastic particles: Dependence on wood species and environmental conditions. Holzforschung 59:72-81.

Montel, M. C., E. Beuvier, and A. Hauwuy. 2003. Pratiques d'élevage, microflore du lait et qualités des produits laitiers. INRA Prod. Anim. 16:279-282.

Nickels, C., and H. Leesment. 1964. Method for the differentiation and quantitative determination of starter bacteria. Milchwissenschaft 19:374-378.

Ogier, J. C., V. Lafarge, V. Girard, A. Rault, V. Maladen, A. Gruss, J. Y. Leveau, and A. Delacroix-Buchet. 2004. Molecular fingerprinting of dairy microbial ecosystems by use of temporal temperature and denaturating gradient gel electrophoresis. Appl. Environ. Microbiol. 70:5628-5643.

Oulahal-Lagsir, N., A. Martial-Gros, M. Bonneau, and J. L. Blum. 2003. "Escherichia coli-milk" biofilm removal from stainless steel surface: Synergism between ultrasonic waves and enzymes. Biofouling 19:159-168.

Prechter, S., M. Betz, G. Cerny, G. Wegener, and E. Windeisen. 2002. Hygiene aspects of wooden resp. plastic cutting boards. Holz als Roh- und Werkstoff. 60:239-248.

Revol-Junelles, A. M., R. Miguindou-Mabiala, D. Roger-Maigne, and J. B. Milliere. 2005. Behavior of Escherichia coli cells and Bacillus cereus spores on poplar wood crates by impedance measurements. J. Food Prot. 68:80-84.

Richard, J. 1997. Utilisation du bois comme matériau au contact des produits laitiers. C.R. Acad. Agric. Fr. 83(5):27-34.

Schönwälder, A., R. Kehr, A. Wulf, and K. Smalla. 2002. Wooden boards affecting the survival of bacteria? Holz als Roh- und Werkstoff. 60:249-257.

Swaffield, C. H., J. A. Scott, and B. Jarvis. 1997. Observations on the microbial ecology of traditional alcoholic cider storage vats. Food Microbiol. 14:353-361.

Welker, C., N. Faiola, S. Davis, I. Maffatore, and C. A. Batt. 1997 Bacterial retention and cleanability of plastic and wood cutting boards with commercial food service maintenance practices. J. Food Prot. 60:407-441.

Wenning, M., V. Theilmann, and S. Scherer. 2006. Rapid analysis of two food-borne microbial communities at the species level by Fourier-transform infrared microspectroscopy. Environ. Microbiol. 8:848-857. 